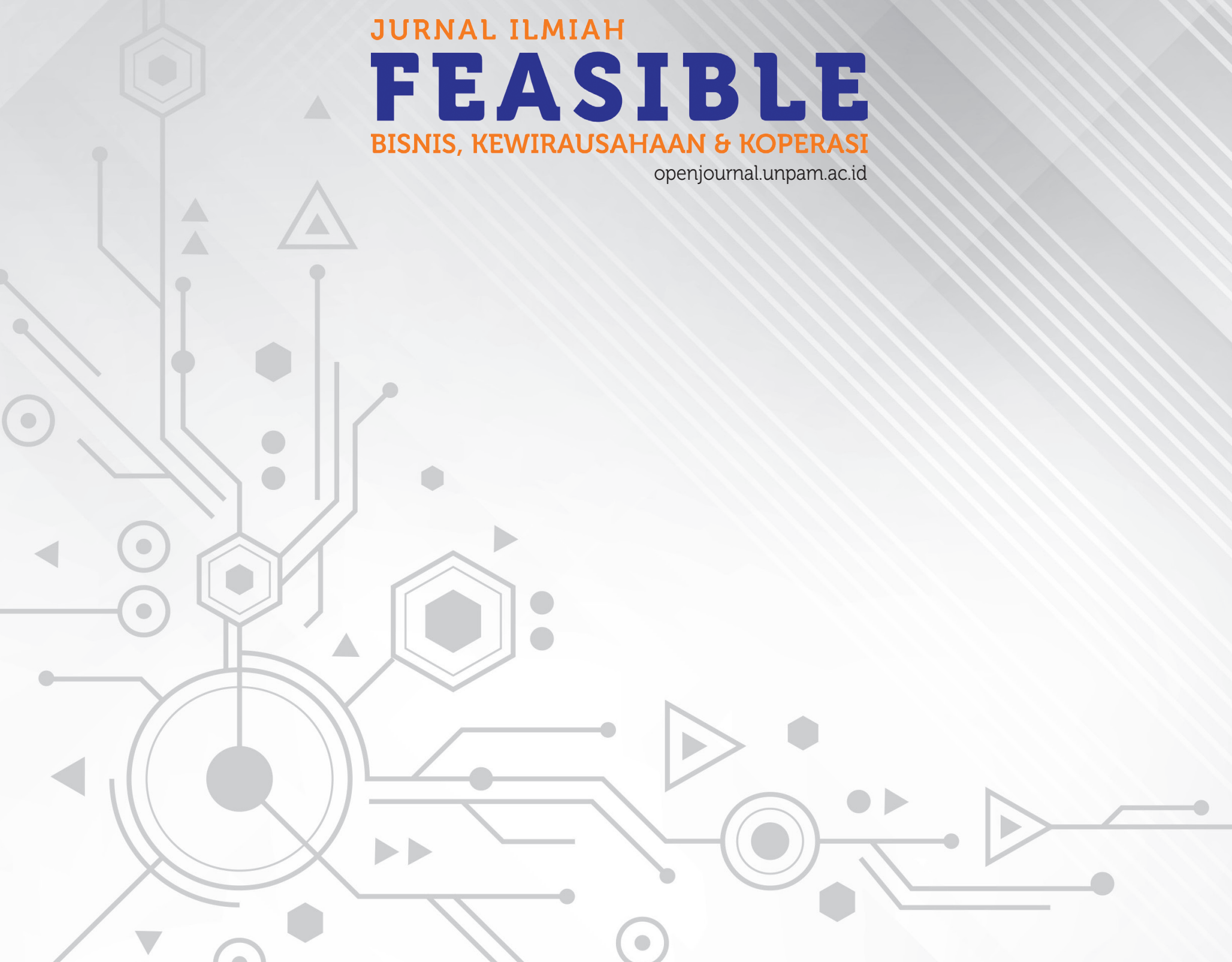




\title{
PENGARUH FAKTOR INDIVIDU DAN LINGKUNGAN TERHADAP KEPUTUSAN MAHASISWA MENJADI WIRAUSAHA Studi Kasus Pada Mahasiswa Universitas Pamulang
}

\author{
Sunanto \\ Fakultas Ekonomi, Universitas Pamulang \\ sunantoapt@gmail.com
}

\begin{abstract}
Abstrak
Tujuan dari penelitian ini adalah untuk mengetahui pengaruh faktor individu dan lingkungan baik secara parsial dan simultan terhadap keputusan menjadi wirausaha pada Mahasiswa Universitas Pamulang. Model penelitian bersifat asosiatif kuantitatif dengan pengujian hipotesis. Populasi dalam penelitian ini adalah Mahasiswa Unpam yang berwirausaha dan jumlah sampel berdasarkan Slovin berjumlah 100 (digenapkan), sampling dengan teknik aksidental metode pengumpulan data melalui kuesioner dengan skala Likert, pengumpulan data melalui kuesioner, observasi dan studi kepustakaan. Teknik analisis data: Uji Validitas, Uji Reliabilitas, Uji asumsi klasik, Uji Regresi Linier, Uji Koefisien Determinan, Uji Parsial (Uji t), dan Uji Simultan (Uji F). Hasil penelitian diperoleh: (1) Terdapat pengaruh yang signifikan antara faktor individu terhadap keputusan menjadi wirausaha

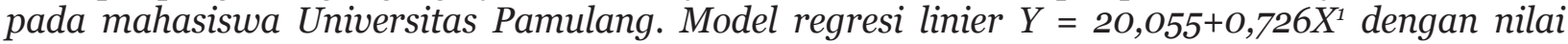
korelasi $r=0,726$ (korelasi kuat), serta nilai $t_{\text {hitung }} 10,439>t_{\text {tabel }} 1,985$ dengan nilai sig.o,ooo $(<0,05)$. (2) Terdapat pengaruh yang signifikan antara faktor lingkungan terhadap keputusan menjadi wirausaha pada mahasiswa Universitas Pamulang. Model regresi linier $Y=7,956+0,705 X^{2}$ dengan nilai korelasi $r=0,705$ (korelasi kuat), serta nilai $t_{\text {hitung }} 9,845>t_{\text {tabel }} 1,985$ dengan nilai sig.o,ooo $(<0,05)$. (3) Terdapat pengaruh yang signifikan antara faktor individu dan lingkungan secara simultan terhadap keputusan menjadi wirausaha pada mahasiswa Universitas Pamulang. Model regresi linier berganda $Y=7,002+0,486 X 1+0,441 X^{2}$, dengan nilai korelasi berganda $R=0,814$ (korelasi sangat kuat), dan nilai koefisen determinasi adjusted $R^{2}$ sebesar 0,656 serta nilai $F_{\text {hitung }}$ $95,575>F_{\text {tabel }} 1,43$ dengan nilai sig.o,ooo $(<0,05)$.
\end{abstract}

Kata Kunci: Kualitas produk, Kualitas pelayanan, Keputusan, Mahasiswa Unpam

\begin{abstract}
The purpose of this study is to determine the influence of individual and environmental factors both partially and simultaneously to the decision to become an entrepreneur at Pamulang University Students. The research model is quantitative associative with hypothesis testing. The population in this study were the students of Unpam and the number of samples based on Slovin amounted to 100 (fulfilled), sampling with accidental technique. Methods of data collection through questionnaires with Likert scale, Data collection through questionnaires, observation and literature study. Data analysis techniques: Validity Test, Reliability Test, Classic Assumption Test, Multiple Linear Regression Test, Determinant Coefficient Test, Partial Test (Test $t$ ) and Simultaneous Test (Test F). The results obtained: (1) There is a significant influence between individual factors on the decision to become an entrepreneur in Pamulang University Students. Linear regression model $Y=20,055+O, 726 X^{i}$, correlation value $r=0,726$ (strong correlation), and value of $t_{\text {count }} 10,439>t_{\text {table }}$ 1,985 with value of sig.0,00O $(<0,05)$. (2) There is a significant influence between environmental factors on the decision to become an entrepreneur in Pamulang University Students. Linear regression model $Y=$ $7,956+0,705 X^{2}$ correlation value $r=0,705$ (strong correlation), and value of $t_{\text {count }} 9,845>t_{\text {table }} 1,985$
\end{abstract}


with value of sig,o,ooo $(<0,05)$. (3) There is a significant influence between individual and environmental factors simultaneously on the decision to become an entrepreneur in Pamulang University Students. Multiple linear regression model $Y=7,002+O, 486 X 1+O, 441 X^{2}$, multiple correlation value $R=0,814$ (very strong correlation), and adjusted $R^{2}$ value equal to 0,656 and $F_{\text {value count }} 95,575>F_{\text {table }} 1,43$ with value of sig, $0,000(<0.05)$.

Keywords: Quality of Product, Quality of Service, Decision, Student of Unpam

\section{PENDAHULUAN \\ Latar Belakang Masalah}

Peningkatan daya saing bangsa salah satunya dapat dilaksanakan melalui peningkatan kemampuan dan keahlian sumber daya khususnya generasi mudanya. Mahasiswa merupakan kelompok generasi muda terdidik yang mempunyai kreatifitas, inovasi dan energi yang relatif lebih baik dan mempunyai kemampuan dan potensi yang sangat besar untuk merubah setiap tantangan menjadi peluang. Sikap mental ini merupakan modal dasar untuk menjadi wirausaha muda kampus yang mandiri, unggul dan profitable.

Kewirausahaan merupakan keniscayaan dalam konteks ketahanan ekonomi suatu bangsa atau masyarakat, dan merupakan salah satu solusi dalam permasalahan lapangan kerja. Seorang pakar entrepreneur dari Amerika Serikat, David McClelland mengatakan bahwa suatu negara akan mencapai tingkat kemakmuran apabila jumlah entrepreneur-nya paling sedikit 2\% dari total jumlah penduduknya.

Universitas Pamulang (Unpam) merupakan kampus swasta dengan jumlah mahasiswa saat ini tidak kurang dari 80.000 mahasiswa dan memiliki dosen hampir 1.900 orang. Dapat dikatakan saat ini Unpam merupakan kampus dengan jumlah mahasiswa terbesar di Indonesia. Dari hasil observasi awal, tidak kurang dari 65\% Mahasiswa Unpam sudah bekerja, dan sebagian kecil (+/- 6,67\%) mempunyai usaha baik skala mikro, kecil, dan menengah. Fenomena penting lainnya yang menarik adalah jumlah mahasiswa yang besar ini ternyata belum sebanding dengan besarnya motivasi untuk berwirausaha. Hal ini sejalan dengan fakta umum dan pendapat para pakar bahwa motivasi berwirausaha masyarakat termasuk mahasiswa secara umum masih rendah yang disebabkan oleh multifaktor. Fenomena di lapangan menunjukkan status sosial wirausaha, khususnya mereka yang baru menapaki dunia usaha, masih belum setinggi mereka yang mempunyai pekerjaaan dan gaji tetap seperti karyawan. Paradigma masyarakat terhadap wirausaha masih relatif belum baik. Faktor lingkungan yang ada diduga masih belum mendukung tumbuh suburnya para wirausaha.

Berdasarkan latar belakang tersebut penulis ingin melakukan penelitian pemasaran dengan judul "Pengaruh Faktor Individu dan Lingkungan Terhadap Keputusan Mahasiswa Menjadi Wirausaha (Studi Kasus Pada Mahasiswa Universitas Pamulang).

\section{Pembatasan Masalah}

Dalam penelitian ini peneliti membatasi masalah pada hal-hal sebagai berikut:

1. Keputusan, khususnya keputusan mahasiswa Unpam menjadi wirausaha.

2. Faktor Individu, khususnya individu mahasiswa.

3. Faktor lingkungan, khususnya lingkungan kampus dan masyarakat.

4. Lokasi penelitian, pada Mahasiswa Universitas Pamulang.

5. Waktu Penelitian, pada bulan Juli- Oktober 2017.

\section{Perumusan Masalah Penelitian}

1. Bagaiamana pengaruh faktor individu terhadap keputusan mahasiswa menjadi wirausaha (pada mahasiswa Universitas Pamulang).

2. Bagaiamana pengaruh faktor lingkungan terhadap keputusan mahasiswa menjadi wirausaha (pada mahasiswa Universitas Pamulang).

3. Bagaimana pengaruh faktor individu dan lingkungan secara simultan terhadap keputusan mahasiswa menjadi wirausaha (pada mahasiswa Universitas Pamulang).

\section{Tujuan Penelitian}

1. Ingin mengetahui pengaruh faktor individu terhadap keputusan mahasiswa menjadi wirausaha (pada mahasiswa Universitas Pamulang).

2. Ingin mengetahui pengaruh faktor lingkungan terhadap keputusan mahasiswa menjadi wirausaha (pada mahasiswa Universitas Pamulang).

3. Ingin mengetahui pengaruh faktor individu dan lingkungan secara simultan terhadap keputusan mahasiswa menjadi wirausaha (pada mahasiswa Universitas Pamulang). 


\section{Tinjauan Pustaka}

\section{Wirausaha}

Wirausaha adalah orang yang memiliki jiwa, sikap, perilaku dan kemampuan kewirausahaan. Sedangkan Kewirausahaan itu sendiri menurut Suryana (2011) adalah adalah kemampuan kreatif dan inovatif yang dijadikan kiat, dasar, sumberdaya, proses, dan perjuangan untuk menciptakan nilai tambah barang dan jasa yang dilakukan dengan keberanian untuk menghadapi risiko. Dalam bagaian lain kewirausahaan merupakan kemampuan kreatif dan inovatif melalui cara-cara yang baru dan berbeda yang dijadikan dasar, kiat, dan sumber daya untuk mencari peluang menuju sukses (dalam Suryana, 2006).

\section{Keputusan}

Menurut Schiffman dalam perilaku Konsumen (2004), keputusan adalah seleksi untuk memilih terhadap dua pilihan atau lebih. Sedangkan proses pengambilan keputusan, menurut Kotler (2009), melalui lima tahap proses yaitu: pengenalan masalah, pencarian alternatif informasi, evaluasi alternatif, keputusan, perilaku pasca keputusan.

\section{Faktor Individu}

Solomon dalam bukunya Consumer Behavior (2011) menyatakan bahwa faktor individu mempengaruhi proses keputusan individu. Dalam bagian lain Schiffman (2004) menyebutkan bahwa faktor individu mencakup faktor: motivasi, kepribadian, persepsi, pembelajaran, sikap, dan komunikasi.

\section{Faktor lingkungan}

Kotler (2009) dalam bukunya Marketing Management edisi ke-13 menyatakan bahwa faktor lingkungan yang mempengaruhi keputusan termasuk diantaranya faktor budaya dan faktor sosial. Dijelaskan lebih lanjut bahwa faktor budaya meliputi budaya, sub budaya, dan kelas sosial. Sementara faktor sosial meliputi kelompok referensi, keluarga, peran, dan status sosial.

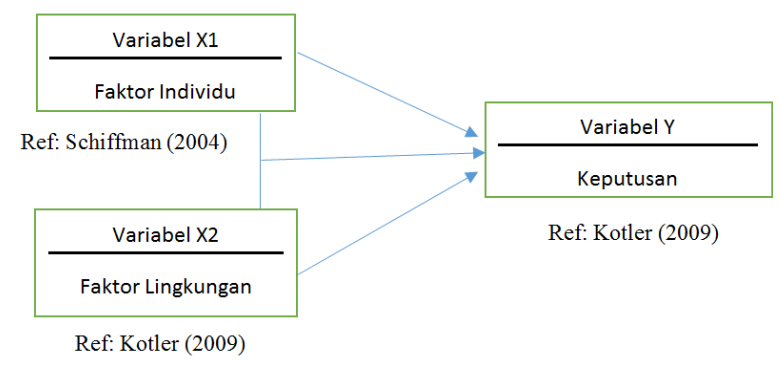

\section{Hipotesis Penelitian}

Berdasarkan rumusan masalah dan tinjauan pustaka, maka diajukan beberapa hipo- tesis penelitian sebagai berikut:

1. Diduga terdapat pengaruh positif dan signifikan dari faktor individu terhadap keputusan mahasiswa menjadi wirausaha

2. Diduga terdapat pengaruh positif dan signifikan dari faktor lingkungan terhadap keputusan mahasiswa menjadi wirausaha

3. Diduga terdapat pengaruh positif dan signifikan dari faktor individu dan lingkungan secara simultan terhadap keputusan mahasiswa menjadi wirausaha

\section{METODOLOGI PENELITIAN Ruang Lingkup Penelitian}

Model penelitian menggunakan pendekatan asosiatif yang bersifat kuantitatif dengan pengujian hipotesis. Lokus penelitian yaitu pada Mahasiswa Universitas Pamulang, serta waktu penelitian yaitu Januari s/d Maret 2018.

\section{Penentuan Populasi dan Sampel}

Populasi dalam penelitian ini adalah Mahasiswa Universitas Pamulang yang tercatat dalam administrasi Universitas Pamulang sampai dengan bulan Agustus 2017. Penentuan jumlah sampel dengan pendekatan rumus Slovin. Penarikan sampel menggunakan teknik aksidental (accidental sampling) terhadap mahasiswa yang mempunyai usaha. Dengan populasi sebanyak $6,67 \%$ x $80.000=5,336$ mahasiswa maka berdasarkan rumus Slovin, dengan tingkat toleransi (e) 10\% maka ukuran sampel sebesar 99,9 dan dibulatkan menjadi 100 mahasiswa.

\section{Sumber Data Penelitian}

Sumber data dalam penelitian ini menggunakan data primer dan sekunder. Data primer didapat melalui penyebaran kuesioner kepada mahasiswa, sementara data sekunder dari lingkungan Universitas Pamulang dan sumber lain-lain yang terkait.

\section{Metode Pengumpulan Data}

Metode pengumpulan data melalui penyebaran kuesioner dengan menggunakan Skala Likert untuk mencari data primer tentang faktor individu, lingkungan, dan keputusan menjadi wirausaha. Alternatif jawaban kuesioner sebagai berikut: Jawaban 1. Sangat Tidak Setuju (STS); 2 Tidak Setuju (TS); 3 Ragu (R); 4 Setuju (S); 5. Sangat Setuju (SS).

\section{Metode Analisis Data}

Dalam penelitian ini menggunakan metode analisis data sebagai berikut: Uji Validitas, Uji Reliabilitas, Uji Asumsi klasik, Model Regresi linier sederhana dan berganda, Koefisien Deter- 
minasi. Analisis data menggunakan bantuan SPSS-21.

\section{Uji Hipotesis}

Uji Hipotesis dengan menggunakan uji partial (Uji t) dan uji simultan (Uji F).

\begin{tabular}{|c|c|c|}
\hline \multicolumn{3}{|c|}{ Operasional Variabel Penelitian } \\
\hline Variabel & Indikator & $\begin{array}{c}\text { Nomor } \\
\text { Pernyataan }\end{array}$ \\
\hline \multicolumn{3}{|l|}{$\left(\right.$ Variabel $\left.X_{1}\right)$} \\
\hline \multirow{6}{*}{ Faktor Individu } & Motivasi & $1-2$ \\
\hline & Kepribadian & $3-4$ \\
\hline & Persepsi & $5-6$ \\
\hline & Pembelajaran & $7-8$ \\
\hline & Sikap & $9-10$ \\
\hline & Komunikasi & $11-12$ \\
\hline \multicolumn{3}{|l|}{$\left(\right.$ Variabel $\left.X_{2}\right)$} \\
\hline \multirow{6}{*}{ Faktor Lingkungan } & Budaya & $13-14$ \\
\hline & Kelas sosial & $15-16$ \\
\hline & Kelompok referensi & $17-18$ \\
\hline & Keluarga & $19-20$ \\
\hline & Peran sosial & $21-22$ \\
\hline & Status sosial & $23-24$ \\
\hline \multicolumn{3}{|l|}{ (Variabel Y) } \\
\hline \multirow{5}{*}{ Keputusan } & Pengenalan masalah & $25-26$ \\
\hline & Pencarian alternatif & $27-28$ \\
\hline & Evaluasi alternatif & $29-30$ \\
\hline & Keputusan & $31-32$ \\
\hline & Perilaku pasca keputusan & $33-34$ \\
\hline
\end{tabular}

\section{HASILPENELITIANDANPEMBAHASAN Objek Penelitian}

Penelitian ini dilaksanakan di Universitas Pamulang. Pemilihan lokasi ini merujuk pada latar belakang dan tujuan penelitian untuk mengetahui dan menganlisis faktor-faktor yang mempengaruhi mahasiswa Unpam menjadi wirausaha. Populasi dalam penelitian ini adalah Mahasiswa Unpam dan jumlah sampel ditentukan dengan rumus Slovin berjumlah 100 mahasiswa (dibulatkan).

\section{Uji Instrumen Penelitian \\ 1. Uji Validitas}

\begin{tabular}{c|c|c|c|c|}
\hline \multicolumn{5}{c}{ Tabel 1.1. Uji Validitas Instrumen } \\
\hline \multirow{4}{*}{ Variabel } & No. Instrumen & $r_{\text {hitung }}$ & $r_{\text {tobel }}$ & Keterangan \\
\hline \multirow{4}{*}{ Individu $\left(X_{1}\right)$} & 1. & 0,538 & 0,198 & Valid \\
\cline { 2 - 5 } & 2. & 0,726 & 0,198 & Valid \\
\cline { 2 - 5 } & 3. & 0,597 & 0,198 & Valid \\
\cline { 2 - 5 } & 4. & 0,705 & 0,198 & Valid \\
\cline { 2 - 5 } & 5. & 0,718 & 0,198 & Valid \\
\cline { 2 - 5 } & 6. & 0,613 & 0,198 & Valid \\
\hline
\end{tabular}

\begin{tabular}{|c|c|c|c|c|}
\hline & 7. & 0,442 & 0,198 & Valid \\
\hline & 8. & 0,626 & 0,198 & Valid \\
\hline & 9. & 0,458 & 0,198 & Valid \\
\hline & 10. & 0,531 & 0,198 & Valid \\
\hline & 11. & 0,567 & 0,198 & Valid \\
\hline & 12. & 0,644 & 0,198 & Valid \\
\hline \multirow{12}{*}{ Lingkungan $\left(\mathrm{X}_{2}\right)$} & 13. & 0,380 & 0,198 & Valid \\
\hline & 14. & 0,316 & 0,198 & Valid \\
\hline & 15. & 0,408 & 0,198 & Valid \\
\hline & 16. & 0,423 & 0,198 & Valid \\
\hline & 17. & 0,412 & 0,198 & Valid \\
\hline & 18. & 0,496 & 0,198 & Valid \\
\hline & 19. & 0,436 & 0,198 & Valid \\
\hline & 20 & 0,526 & 0,198 & Valid \\
\hline & 21. & 0,487 & 0,198 & Valid \\
\hline & 22. & 0,389 & 0,198 & Valid \\
\hline & 23. & 0,472 & 0,198 & Valid \\
\hline & 24 & 0,351 & 0,198 & Valid \\
\hline \multirow{10}{*}{ Keputusan (Y) } & 25. & 0,457 & 0,198 & Valid \\
\hline & 26. & 0,529 & 0,198 & Valid \\
\hline & 27. & 0,420 & 0,198 & Valid \\
\hline & 28. & 0,641 & 0,198 & Valid \\
\hline & 29. & 0,472 & 0,198 & Valid \\
\hline & 30 & 0,521 & 0,198 & Valid \\
\hline & 31. & 0,325 & 0,198 & Valid \\
\hline & 32. & 0,654 & 0,198 & Valid \\
\hline & 33. & 0,381 & 0,198 & Valid \\
\hline & 34. & 0,540 & 0,198 & Valid \\
\hline
\end{tabular}

Dari tabel 1.1. dapat disimpulkan bahwa seluruh instrumen dari variabel faktor individu, variabel lingkungan, dan variabel keputusan memiliki nilai $\mathrm{r}_{\text {hitung }}$ lebih besar dari $\mathrm{r}_{\text {tabel }}$ yaitu o,198. Dengan demikian seluruh instrumen dinyatakan valid. Nilai $r_{\text {tabe }}$ menggunakan basis 100 responden dan tingkat kesalahan 0,05 (two tail).

\section{Uji Reliabilitas}

\begin{tabular}{|l|c|c|c|}
\hline \multicolumn{5}{|c|}{ Tabel 1.2. Uji Reliabilitas } \\
Variabel & $\begin{array}{c}\text { Cronbach's } \\
\text { Alpha }\end{array}$ & $\begin{array}{c}\text { Cronbach's Alpha Based } \\
\text { on Standardized Items }\end{array}$ & N of Items \\
\hline Variabel $\left(\mathrm{X}_{1}\right)$ &, 839 &, 836 & 12 \\
\hline Variabel $\left(\mathrm{X}_{2}\right)$ &, 580 &, 091 & 12 \\
\hline Variabel $(\mathrm{Y})$ &, 662 &, 657 & 10 \\
\hline \multicolumn{4}{|c|}{ Sumber: Data Diolah } \\
\hline
\end{tabular}

Dari tabel 4.2. dapat dismpulkan bahwa semua variabel $\left(\mathrm{X}_{1}, \mathrm{X}_{2}\right.$, dan $\left.\mathrm{Y}\right)$ memiliki nilai $\mathrm{r}_{\mathrm{ac}}$ hitung lebih besar dari $\mathrm{r}_{\mathrm{ac}}$ tabel yaitu 0,198. Dengan demikian semua variabel dinyatakan reliabel. Nilai $r_{a c}$ tabel menggunakan basis 100 
responden dan tingkat kesalahan 0,05 (two tail).

\section{Uji Asumsi Klasik}

\section{Uji Normalitas}

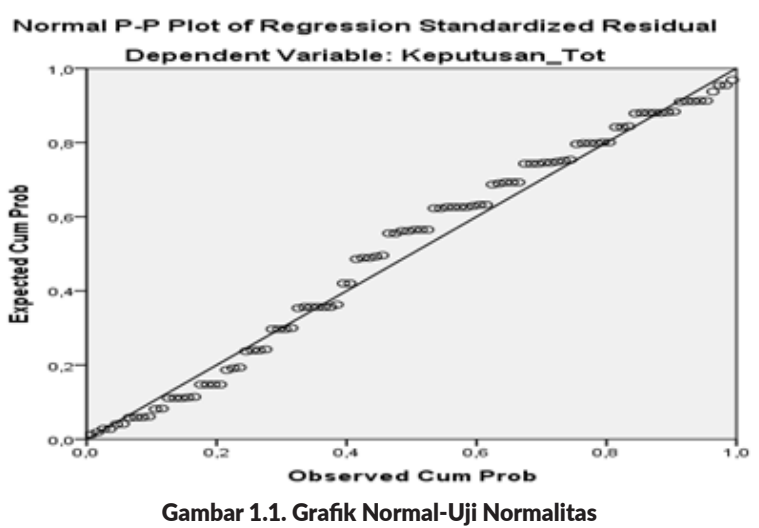

Sumber : Data diolah

Dilihat dari grafik normalnya menunjukkan pola distribusi titik-titik di sekitar garis diagonal, sehingga disimpulkan data berdistribusi normal atau memenuhi persyaratan normalitas.

\section{Uji Multikolinieritas}

\begin{tabular}{|c|c|c|c|c|c|c|c|}
\hline \multicolumn{8}{|c|}{ Tabel 1.3. Nilai VIF Variabel Independen } \\
\hline \multirow[b]{2}{*}{ Model } & \multicolumn{2}{|c|}{$\begin{array}{l}\text { Unstandardized } \\
\text { Coefficients }\end{array}$} & \multirow{2}{*}{$\begin{array}{c}\text { Standardized } \\
\text { Coefficients } \\
\text { Beta } \\
\end{array}$} & \multirow[b]{2}{*}{$t$} & \multirow[b]{2}{*}{ Sig. } & \multicolumn{2}{|c|}{ Collinearity Statistics } \\
\hline & B & $\begin{array}{l}\text { Std. } \\
\text { Error }\end{array}$ & & & & Tolerance & VIF \\
\hline (Constant) & 7,002 & 2,575 & & 2,719 & 008 & & \\
\hline Individu_Tot & ,282 & ,041 & , 486 & 6,919 & ,000 & ,704 & 1,420 \\
\hline Lingkungan_Tot & , 413 & .066 & ,441 & 6,280 & , ,000 &, 704 & 1,420 \\
\hline \multicolumn{8}{|c|}{ a. Dependent Variable: Keputusan_Tot } \\
\hline & & & & & & Sumber: $\mathrm{L}$ & diolah \\
\hline
\end{tabular}

Dari data tabel 4.3, nilai VIF Faktor Individu maupun Lingkungan memliki nilai yang sama yaitu sebesar 1,420 atau kurang dari 10, maka dapat dismpulkan model regresi yang terbentuk tidak terjadi multikolinieritas.

\section{Uji Heterokedastisitas}

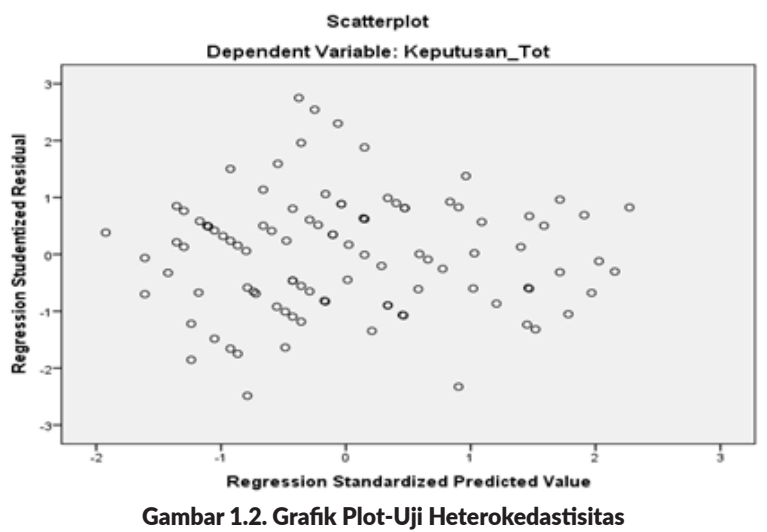

Dilihat dari grafik plot dapat dilihat sebaran titik-titik yang acak baik di bawah/atas angka nol dari sumbu Y. Dengan demikian dapat disimpulkan tidak terjadi heterokedastisitas.

\section{Model Regresi Linier}

\section{Sederhana dan Berganda}

\section{Model Regresi Linier Sederhana}

Tabel 1.4. Koefisien-Regresi Linier Variabel $\mathrm{X}$

\begin{tabular}{|c|c|c|c|c|c|c|}
\hline & & \multicolumn{2}{|c|}{$\begin{array}{l}\text { Unstandardized } \\
\text { Coefficients }\end{array}$} & \multirow{2}{*}{$\begin{array}{c}\text { Standardized } \\
\text { Coefficients } \\
\text { Beta }\end{array}$} & \multirow[b]{2}{*}{$\mathrm{t}$} & \multirow[b]{2}{*}{ Sig. } \\
\hline \multicolumn{2}{|c|}{ Model } & B & Std. Error & & & \\
\hline \multirow[t]{2}{*}{1} & (Constant) & 20,055 & 1,794 & & 11,178 &, 000 \\
\hline & Individu_Tot & ,422 & ,040 & ,726 & 10,439 & ,000 \\
\hline \multicolumn{7}{|c|}{ a. Dependent Variable: Keputusan_Tot } \\
\hline
\end{tabular}

Dari tabel 1.4. model regresi linier yang didapatkan adalah $\mathrm{Y}=20,055+0,726 \mathrm{X}_{1}$

Tabel 1.5. Koefisien-Regresi Linier Variabel $\mathrm{X}_{2}$

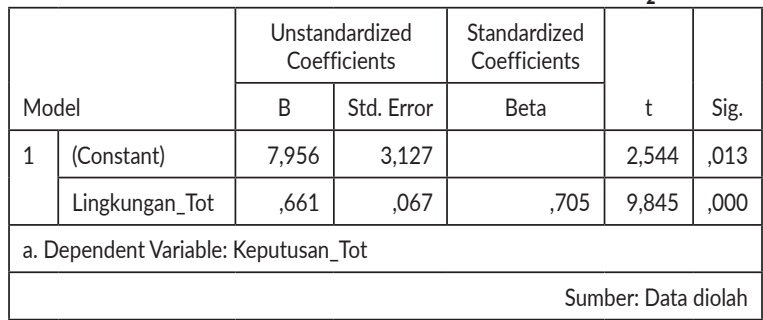

Dari tabel 1.5. model regresi linier yang didapatkan adalah $\mathrm{Y}=7,956+0,705 \mathrm{X}_{2}$

\section{Model Regresi Linier Berganda}

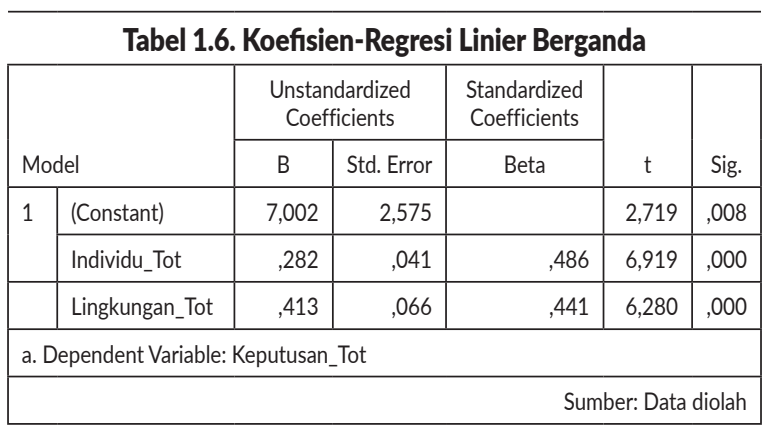

Dari tabel 1.6. maka model regresi linier berganda yang didapatkan adalah $\mathrm{Y}=7,002+$ $0,486 X_{1}+0,441 X_{2}$

\section{Pengujian Hipotesis}

1. Hipotesis 1 (Pengaruh Faktor individu terhadap keputusan menjadi wirausaha) dengan uji t. 


\begin{tabular}{|c|c|c|c|c|c|c|}
\hline \multicolumn{7}{|c|}{ Tabel 1.7. Nilai Signifikansi Hipotesis-1 } \\
\hline & & $\begin{array}{r}\text { Unstan } \\
\text { Coef }\end{array}$ & $\begin{array}{l}\text { lardized } \\
\text { cients }\end{array}$ & $\begin{array}{l}\text { Standardized } \\
\text { Coefficients }\end{array}$ & & \\
\hline \multicolumn{2}{|c|}{ Model } & B & Std. Error & Beta & $\mathrm{t}$ & Sig. \\
\hline \multirow[t]{2}{*}{1} & (Constant) & 20,055 & 1,794 & & 11,178 & 000 \\
\hline & Individu_Tot & 422 & ,040 & ,726 & 10,439 & ,000 \\
\hline \multicolumn{7}{|c|}{ a. Dependent Variable: Keputusan_Tot } \\
\hline
\end{tabular}

Didapat nilai $\mathrm{t}_{\text {hitung }}=10,439$ sig. $=0,00$ dan nilai $\mathrm{t}_{\text {tabel }}(100,95 \%)=1,985$.

Kriteria: Daerah kritis, $\mathrm{H}_{0}$ ditolak jika nilai signifikansi $<0.05$.

Hasil: Karena $\mathrm{t}_{\text {hitung }}>\mathrm{t}_{\text {tabel }}$ dan sig. $<0,05$ maka $\mathrm{H}_{\mathrm{o}}$ ditolak dan $\mathrm{H}_{\mathrm{a}}$ Diterima.

2. Hipotesis 2 (Pengaruh Faktor lingkungan terhadap keputusan menjadi wirausaha) dengan uji $t$

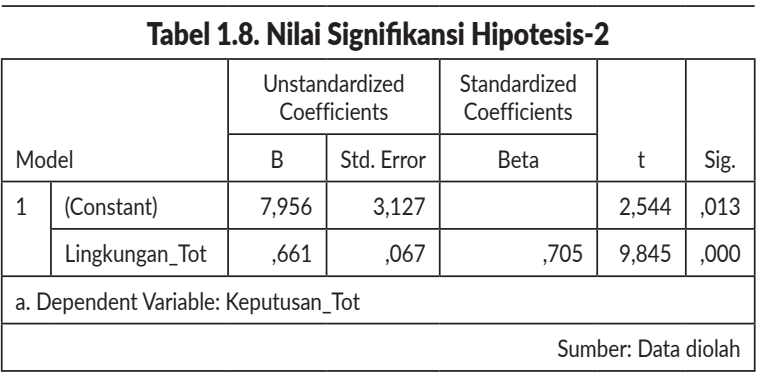

Di dapat nilai $\mathrm{t}_{\text {hitung }}=9,845 \mathrm{sig} .=0,00$ dan nilai $_{\text {tabel }}(100,95 \%)=1,985$

Kriteria: Daerah kritis, $\mathrm{H}_{0}$ ditolak jika nilai signifikansi < 0.05

Hasil: Karena $\mathrm{t}_{\text {hitung }}>\mathrm{t}_{\text {tabel }}$ dan sig. $<0,05$ maka $\mathrm{H}_{\mathrm{o}}$ ditolak dan $\mathrm{H}_{\mathrm{a}}$ Diterima

3. Hipotesis 3 (Pengaruh Faktor individu dan lingkungan secara simultan terhadap keputusan menjadi wirausaha) dengan uji $\mathrm{F}$.

\begin{tabular}{|c|c|c|c|c|c|c|}
\hline \multicolumn{7}{|c|}{ Tabel 1.9. Nilai Signifikansi Hipotesis-3 } \\
\hline \multicolumn{2}{|c|}{ Model } & $\begin{array}{l}\text { Sum of } \\
\text { Squares }\end{array}$ & df & $\begin{array}{l}\text { Mean } \\
\text { Square }\end{array}$ & $\mathrm{F}$ & Sig. \\
\hline \multirow[t]{3}{*}{1} & Regression & 489,408 & 2 & 244,704 & 95,575 &, $000^{\mathrm{b}}$ \\
\hline & Residual & 248,352 & 97 & 2,560 & & \\
\hline & Total & 737,760 & 99 & & & \\
\hline \multicolumn{7}{|c|}{$\begin{array}{l}\text { a. Dependent Variable: Keputusan_Tot } \\
\text { b. Predictors: (Constant), Lingkungan_Tot, Individu_Tot }\end{array}$} \\
\hline \multicolumn{7}{|c|}{ Sumber: Data diolah } \\
\hline
\end{tabular}

Didapat nilai $\mathrm{F}_{\text {hitung }}=95,575$ sig. $=0$,oo dan nilai $\mathrm{F}_{\text {tabel }}(100,95 \%)=1,43$.

Kriteria: Daerah kritis, $\mathrm{H}_{\mathrm{o}}$ ditolak jika nilai signifikansi $<0.05$.

Hasil: Karena $\mathrm{F}_{\text {hitung }}>\mathrm{F}_{\text {tabel }}$ dan sig. $<0,05$ maka $\mathrm{H}_{\mathrm{o}}$ ditolak dan $\mathrm{H}_{\mathrm{a}}$ diterima.

\section{Pengujian Koefisien Determinasi (adjusted $\mathrm{R}^{2}$ )}

Tabel 1.10. Nilai Koefisien Determinasi-Variabel $X$

\begin{tabular}{|c|c|c|c|c|}
\hline Model & $R$ & R Square & Adjusted R Square & $\begin{array}{c}\text { Std. Error of the } \\
\text { Estimate }\end{array}$ \\
\hline 1 &, $726^{\mathrm{a}}$ &, 527 &, 522 & 1,888 \\
\hline $\begin{array}{l}\text { a. Predictors: (Constant), Individu_Tot } \\
\text { b. Dependent Variable: Keputusan_Tot }\end{array}$ \\
\hline \multicolumn{5}{|l}{ Sumber: Data diolah } \\
\hline
\end{tabular}

Nilai adjusted $\mathrm{R}^{2}$ untuk variabel $\mathrm{X}_{1}$ (Faktor Individu $=0,522$.

Tabel 1.11. Nilai Koefisien Determinasi-Variabel $\mathrm{X}_{2}$

\begin{tabular}{|c|c|c|c|c|}
\hline Model & $\mathrm{R}$ & R Square & Adjusted R Square & $\begin{array}{c}\text { Std. Error of the } \\
\text { Estimate }\end{array}$ \\
\hline 1 &, $705^{\mathrm{a}}$ &, 497 &, 492 & 1,945 \\
\hline $\begin{array}{l}\text { a. Predictors: (Constant), Lingkungan_Tot } \\
\text { b. Dependent Variable: Keputusan_Tot }\end{array}$ \\
\hline \multicolumn{5}{|l}{ Sumber: Data diolah } \\
\hline
\end{tabular}

Nilai adjusted $\mathrm{R}^{2}$ untuk variabel $\mathrm{X}_{2}$ (Faktor Lingkungan $)=0,492$

Tabel 1.12. Nilai Koefisien Determinasi Berganda
\begin{tabular}{|c|c|c|c|c|}
\hline Model & $R$ & R Square & Adjusted R Square & $\begin{array}{c}\text { Std. Error of the } \\
\text { Estimate }\end{array}$ \\
\hline 1 &, $814^{\text {a }}$ &, 663 &, 656 & 1,600 \\
\hline a. Predictors: (Constant), Lingkungan_Tot, Individu_Tot \\
\hline \multicolumn{4}{|l}{ Sumber: Data diolah } \\
\hline
\end{tabular}

Dari tabel 1.12 di dapat nilai koefisien korelasi berganda sebesar 0,814 yang menunjukkan hubungan yang sangat kuat antara faktor individu dan lingkungan secara simultan terhadap keputusan mahasiswa Unpam menjadi wirausaha. Nilai $\mathrm{R}$ adjusted secara simultan sebesar 0,656 menunjukkan bahwa kontribusi faktor individu dan lingkungan secara simultan mempunyai kontribusi sebesar 65,6\% terhadap keputusan mahasiswa Unpam menjadi wirausaha dan sisanya 34, 4\% dipengaruhi oleh variabel lain yang tidak diteliti.

\section{PEMBAHASAN}

\section{Pengaruh Faktor Individu terhadap keputusan mahasiswa menjadi wira- usaha (pengaruh $\mathrm{X}_{1}$ terhadap $\mathrm{Y}$ )}

Dari model regresi yang didapat, nilai korelasi $(\mathrm{r})$ dari faktor individu ( $\mathrm{X}_{1}$ ) dengan keputusan (Y) sebesar 0,726. Nilai $r$ ini menginterpretasikan korelasi positif yang kuat. Koefisien Determinasi menunjukkan kontribusi sebesar 0,052 atau 52,2\% terhadap keputusan. Dari data tersebut dibuktikan bahwa terdapat hubungan positif yang kuat antara variabel $\mathrm{X}_{1}$ 
terhadap variabel $Y$. Dengan nilai $t_{\text {hitung }}$ yang lebih besar dari $t_{\text {tabel }}$ dan p.sig. <0,05 menunjukkan signifikansi pengaruh variabel independen $\mathrm{X}_{1}$ terhadap variabel dependen $\mathrm{Y}$. Berdasarkan pengujian hipotesis di atas dapat dibuktikan bahwa terdapat pengaruh yang positif dan signifikan antara faktor individu terhadap keputusan menjadi wirausaha pada mahasiswa Universitas Pamulang.

Hasil ini sesuai dengan teori dari Solomon dalam bukunya Consumer Behavior (2011) yang menyatakan bahwa faktor individu mempengaruhi proses keputusan individu.

\section{Pengaruh Lingkungan Terhadap ke- putusan mahasiswa menjadi wira- usaha (pengaruh $\mathrm{X}_{2}$ terhadap $\mathrm{Y}$ ).}

Dari model regresi yang didapat, nilai korelasi (r) lingkungan $\left(\mathrm{X}_{2}\right)$ dengan keputusan (Y) sebesar 0,705. Nilai ini menginterpretasikan adanya korelasi positif yang kuat. Koefisien Determinasi menunjukkan kontribusi sebesar o,492 atau 49,2\% terhadap keputusan. Dari data tersebut dibuktikan bahwa terdapat hubungan positif yang kuat antara variabel independen $\mathrm{X}_{1}$ terhadap variabel dependen $\mathrm{Y}$. Dengan nilai $\mathrm{t}_{\text {hitung }}$ yang lebih besar dari $\mathrm{t}_{\text {tabel }}$ dan p.sig. <0,05 menunjukkan signifikansi pengaruh variabel independen $\mathrm{X}_{1}$ terhadap variabel dependen Y. Berdasarkan pengujian hipotesis di atas dapat dibuktikan bahwa terdapat pengaruh yang positif dan signifikan antara lingkungan terhadap keputusan menjadi wirausaha pada mahasiswa Universitas Pamulang.

Hasil ini sesuai dengan teori dari Kotler (2009) yang menyatakan dalam bukunya Marketing Management bahwa faktor lingkungan mempengaruhi suatu keputusan.

\section{Pengaruh Faktor Individu dan Ling- kungan secara simultan terhadap keputusan mahasiswa menjadi wira- usaha (pengaruh $X_{1}$ dan $X_{2}$ secara simultan terhadap $Y$ ) \\ Dari model regresi berganda yang didapat,} nilai korelasi ganda $(\mathrm{R})$ faktor individu $\left(\mathrm{X}_{1}\right)$ dan lingkungan $\left(\mathrm{X}_{2}\right)$ terhadap keputusan (Y) sebesar o,814 dan ini tergolong korelasi positif yang sangat kuat. Koefisien Determinasi menunjukkan kontribusi positif sebesar 0,656 atau $65,6 \%$ terhadap terhadap keputusan. Dari data di atas dibuktikan bahwa terdapat hubungan positif yang sangat kuat antara variabel independen $X_{1}$ dan $X_{2}$ secara simultan terhadap variabel dependen $\mathrm{Y}$. Dengan nilai $\mathrm{F}_{\text {hitung }}$ yang lebih besar dari $\mathrm{F}_{\text {tabel }}$ dan p.sig. $<0,05$ menunjukkan adanya signifikansi pengaruh variabel independen $\mathrm{X}_{1}$ dan $\mathrm{X}_{2}$ secara simultan terhadap variabel dependen ${ }^{2} \mathrm{Y}$. Berdasarkan pengujian hipotesis di atas dibuktikan bahwa terdapat pengaruh yang positif dan signifikan antara faktor individu dan lingkungan secara simultan terhadap keputusan menjadi wirausaha pada mahasiswa Universitas Pamulang.

Hasil ini sesuai dengan teori dari Solomon (2011) dan Kotler (2009) yang menyatakan keputusan idividu dipengaruhi baik oleh faktor individu dan atau faktor lingkungan.

Dalam model regresi berganda didapat Faktor individu mempunyai koefsien yang lebih tinggi $(0,486)$ dibandingkan dengan faktor lingkungan sebesar $(0,441)$. Hal ini menunjukkan bahwa faktor individu mempunyai pengaruh yang relatif lebih tinggi dibandingkan faktor lingkungan terhadap keputusan menjadi wirausaha pada mahasiswa Universitas Pamulang.

\section{SIMPULAN}

\section{Kesimpulan}

1. Faktor individu berpengaruh positif dan signifikan terhadap keputusan mahasiswa menjadi menjadi wirausaha (pada mahasiswa Universitas Pamulang). Hal ini terbukti dari model regresi linier $\mathrm{Y}=20,055+$ $0,726 \mathrm{X}_{1}$ dan uji $\mathrm{t}_{\text {hitung }}(10,439)>\mathrm{t}_{\text {tabel }}(1,985)$ dengan signifikansi (p.sig.) sebesar 0,oo. Faktor Individu mempunyai kontribusi sebesar 52,2\% terhadap keputusan mahasiswa Unpam menjadi wirausaha.

2. Faktor Lingkungan berpengaruh positif dan signifikan terhadap keputusan mahasiswa menjadi wirausaha (pada mahasiswa Universitas Pamulang). Hal ini terbukti dari model regresi linier $\mathrm{Y}=7,956+0,705 \mathrm{X}_{2}$ dan uji $\mathrm{t}_{\text {hitung }}(9,845)>\mathrm{t}_{\text {tabel }}(1,985)$ dengan signifikansi (p.sig.) sebesar 0,oo. Faktor lingkungan mempunyai kontribusi sebesar 49,2\% terhadap keputusan mahasiswa Unpam menjadi wirausaha.

3. Faktor individu dan lingkungan secara simultas berpengaruh positif dan signifikan terhadap keputusan mahsiswa menjadi menjadi wirausaha (pada mahasiswa Universitas Pamulang). Hal ini terbukti dari model regresi berganda $\mathrm{Y}=7,002+0,486 \mathrm{X}_{1}+0,441 \mathrm{X}_{2}$ dan uji $\mathrm{F}_{\text {hitung }}(95,575)>\mathrm{F}_{\text {tabel }}(1,43)$ dengan signifikansi (p.sig.) sebesar o,oo. Faktor Individu dan lingkungan secara simultan mempunyai kontribusi sebesar 65,6\% terhadap keputusan mahasiswa Unpam menjadi wirausaha, dan selebihnya 34,4\% dipengaruhi faktor lain yang tidak diteliti. 


\section{Saran}

1. Dalam faktor individu, persepsi merupakan indikator yang paling lemah diantara indikator lain. Hal ini perlu adanya perubahan mindset dikalangan mahasiswa dan masyarakat pada umumnya untuk memposisikan dan menilai para wirausaha sejajar dengan kelompok pencari income tetap lainnya.

2. Dalam faktor lingkungan, budaya merupakan faktor yang paling lemah dan dianggap menghambat tumbuhnya sikap mental kewirausahaan. Budaya di sini mengacu pada anggapan umum bahwa bekerja dan mendapatkan penghasilan tetap lebih baik dari pada sebagai wirausaha yang tidak pasti penghasilannya. Oleh karenanya perlu perubahan kultur di masyarakat melalui pendidikan dan pemahaman dari seluruh stakeholder di masyarakat.

3. Dalam hal keputusan, indikator keputusan merupakan yang terlemah yang diperlihatkan oleh mahasiswa. Perlunya pemupukan keberanian untuk mengambil keputusan dengan mengambil risiko yang terukur untuk menjadi wirausaha melalui pendidikan dan pelatihan serta pendampingan dari berbagai lembaga terkait secara berkesinambungan.

4. Untuk penelitian selanjutnya diharapakan bisa ditambahkan faktor-faktor lain yang berpengaruh terhadap keputusan mahasiswa menjadi wirausaha misalnya faktor peluang usaha, dukungan fasilitas usaha yang yang tersedia, pelatihan usaha atau pendampingan seperti adanya pusat inkubasi bisnis dan kewirausahaan di lingkungan kampus yang didukung secara nyata oleh seluruh pihak terkait.

\section{DAFTAR PUSTAKA}

Fahmi, Irham. 2013. Kewirusahaan. Teori, Kasus, dan Solusi. Bandung: AlfaBeta

Kotler, Philip, and Keller K. L. 2009. Marketing Management. $13^{\text {th }}$ Edition. New Jersey. Pearson, Prentice Hall.

Kotler, Philip, dan Keller K. L. 2009. Manajemen Pemasaran. Terjemahan, Edisi Ketigabelas. Jilid 1. Jakarta: Erlangga

Malhotra, Naresh K, Riset Pemasaran. Pendekatan Terapan. Edisi Keempat. Jakarta: Indeks Group Gramedia

Schiffman, Leon, dan Kanuk L.L. 2004. Perilaku Konsumen. Terjemahan, Edisi Ketujuh. Jakarta: Indeks Group Gramedia

Solomon, Michael R. 2011. Consumer Behavior. Buying, Having, and Being. Global
Edition. Ninth Edition. New Jersey. Pearson, Prentice Hall.

Sugiyono. 2012. Metode Penelitian Kuantitatif Kualitatif dan R\&D. Bandung. AlfaBeta

Suryana, Kewirausahaan. 2006. Pedoman Praktis: Kiat dan Proses Menuju Sukses. Jakarta: Salemba Empat.

Umar, Husein. 2005. Pemasaran dan perilaku Konsumen. Jakarta: Gramedia Pustaka Utama

Widjaya, T. 2011. Cepat Menguasai SPSS-19. Jakarta: Cahaya Atma 